\title{
Organocatalytic Enantioselective Alkylation of Pyrazol-3-ones with Isatin-Derived Ketimines: Stereocontrolled Construction of Vicinal Tetrasubstituted Stereocenters
}

\author{
Fares Ibrahim Amr, ${ }^{\mathrm{a}}$ Carlos Vila, ${ }^{\mathrm{a} *}$ Gonzalo Blay, ${ }^{\mathrm{a}}$ M. Carmen Muñoz ${ }^{\mathrm{b}}$ and José R. \\ Pedro $^{\mathrm{a}, *}$ \\ a Departament de Química Orgànica, Facultat de Química, Universitat de València, Dr. Moliner 50, 46100 Burjassot, \\ València (Spain); \\ [phone: +0034963544329; e-mail: carlos.vila@uv.es; jose.r.pedro@uv.es] \\ b Departament de Física Aplicada, Universitat Politècnica de València, Camí de Vera s/n, 46022 València (Spain)
}

Received: ((will be filled in by the editorial staff))

Supporting information for this article is available on the WWW under http://dx.doi.org/10.1002/adsc.201\#\#\#\#\#\#.((Please delete if not appropriate))

\begin{abstract}
Quinine derived thiourea catalysed the enantioselective addition of 4-substituted pyrazolones to isatin-derived ketimines, providing a variety of amino oxindole-pyrazolone adducts containing congested vicinal tetrasubstituted stereocenters with excellent outcomes (up to $98 \%$ yield, $>20: 1 \mathrm{dr}$ and $98 \%$ ee).
\end{abstract}

Keywords: asymmetric catalysis; ; pyrazolones ; isatinderived ketimines; organocatalysis; quaternary stereocenters

The catalytic enantioselective synthesis of building blocks with contiguous quaternary stereocenters is a hot topic because of the prevalence of such structural motifs in natural and bioactive compounds. ${ }^{[1]}$ This goal represents one of the greatest challenges in organic synthesis, due to the steric congestion making difficult the selective C-C bond formation. ${ }^{[2]}$ In this context, the efficient assembly of multifunctionalised heterocyclic compounds containing quaternary stereocenters is of great importance. For example, the 3-substituted 3amino-2-oxindole ${ }^{[3]}$ skeleton bearing a tetrasubstituted stereogenic center at the 3-position is a privileged heterocyclic structure present in many biologically active natural products and pharmaceutical drugs (SSR 149415, ${ }^{[4]}$ AG-041R ${ }^{[5]}$ or NITD609 ${ }^{[6]}$. The addition of nucleophiles to isatinderived ketimines is one of the most straightforward methodology established for synthesis of chiral 3substituted 3-amino-2-oxindole. ${ }^{[3 b, 7]}$ However, only few succesful examples have been described for the assembly of vicinal tetrasubstituted stereogenic centers using isatin-derived ketimines as electrophiles. ${ }^{[8]}$ On the other hand, the pyrazolone is a prominent heterocycle, ${ }^{[9]}$ which exists in plenty of biologically active coumpounds with antiinflamatory, antiviral, antitumor or antibacterial properties, ${ }^{[10]}$ moreover, pyrazol-3-ones are present in numerous pharmaceutical compounds (edaravone, ${ }^{[1]}$ metamizole ${ }^{[12]}$ or remogliflozin etabonate ${ }^{[13]}$. Despite the importance of pyrazolone derivatives, the examples of the synthesis of optically pure 4,4disubstituted-3-pyrazolones are scarce. ${ }^{[14,15]}$ Very recently Yuan, ${ }^{[15 \mathrm{a}]}$ Feng, ${ }^{[15 \mathrm{~b}-\mathrm{d}]}$ Rios $^{[15 \mathrm{e}-\mathrm{f}]}$ and Gong ${ }^{[15 \mathrm{~g}]}$ described the enantioselective additions of 4substituted pyrazolone derivatives to different electrophiles, for the synthesis of pyrazolone bearing a chiral quaternary stereocenter. However, the addition of 4-substituted pyrazolone derivatives to ketimines has not been described. ${ }^{[16]}$

Herein, we wish to report the addition of 4-substituted pyrazolones to isatin-derived ketimines using a bifunctional organocatalyst, leading to chiral heterocyclic compounds containing both amino oxindole and pyrazolone moieties bearing vicinal quaternary stereocenters with good yields and excellent diastereo- and enantioselectivity (Figure 1).

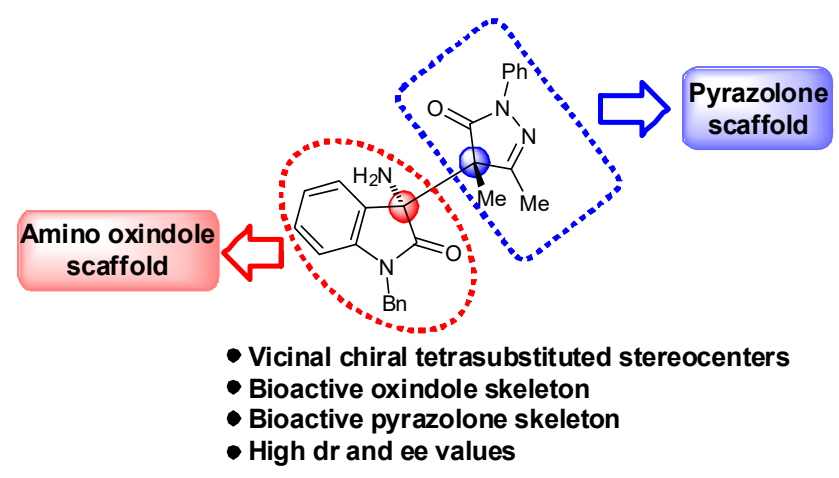

Figure 1. Construction of vicinal tetrasubstituted stereogenic centers in the addition of pyrazol-3-ones to isatin-derived ketimines.

Our initial studies were focused on the addition of 4,5dimethyl-2-phenyl-2,4-dihydro-3H-pyrazol-3-one (2a) to isatin-derived $N$-Boc ketimine 1a in the presence of a series of bifunctional organocatalysts. ${ }^{[17]}$ 
Table 1. Optimization of the reaction conditions. ${ }^{\text {a }}$

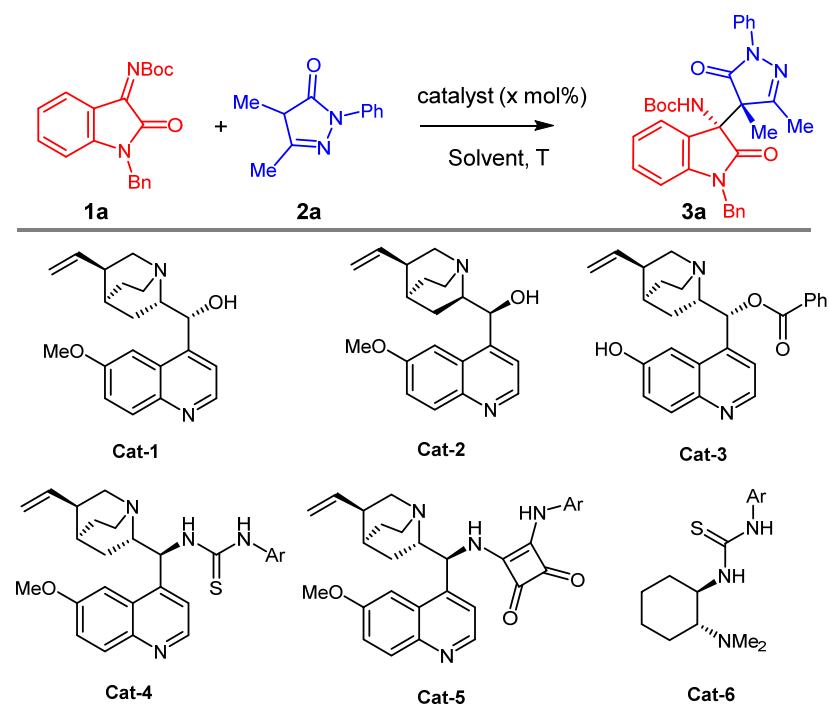

\begin{tabular}{lllllll}
\hline Entry & $\begin{array}{l}\text { Catal. } \\
(\mathrm{mol} \%)\end{array}$ & t(h) & $\begin{array}{l}\text { Conv. } \\
(\%)^{\mathrm{b}}\end{array}$ & d. r. $^{\mathrm{b}}$ & $\begin{array}{l}\text { ee maj } \\
(\%)^{\mathrm{c}}\end{array}$ & $\begin{array}{l}\text { ee } \\
\text { min } \\
(\%)^{\mathrm{c}}\end{array}$ \\
\hline 1 & $\begin{array}{l}\text { Cat-1 } \\
(5 \%)\end{array}$ & 2 & Full & $5: 1$ & 18 & 9 \\
2 & $\begin{array}{l}\text { Cat-2 } \\
(5 \%)\end{array}$ & 2 & 98 & $6: 1$ & $66^{\mathrm{d}}$ & $15^{\mathrm{d}}$ \\
3 & $\begin{array}{l}\text { Cat-3 } \\
(5 \%)\end{array}$ & 1 & Full & $2: 1$ & 27 & $49^{\mathrm{d}}$ \\
4 & $\begin{array}{l}\text { Cat-4 } \\
(5 \%)\end{array}$ & 1 & Full & $>20: 1$ & 96 & n.d. \\
5 & $\begin{array}{l}\text { Cat-5 } \\
(5 \%)\end{array}$ & 1 & Full & $>20: 1$ & 95 & n. d. \\
6 & $\begin{array}{l}\text { Cat-6 } \\
(5 \%)\end{array}$ & 1 & Full & $4: 1$ & $91^{\mathrm{d}}$ & $63^{\mathrm{d}}$ \\
$7^{\mathrm{e}}$ & $\begin{array}{l}\text { Cat-4 } \\
(5 \%)\end{array}$ & 2 & Full & $8: 1$ & 84 & 18 \\
$8^{\mathrm{f}}$ & $\begin{array}{l}\text { Cat-4 } \\
(5 \%)\end{array}$ & 2 & Full & $18: 1$ & 96 & n. d. \\
9 & $\begin{array}{l}\text { Cat-4 } \\
(2 \%)\end{array}$ & 1,5 & Full & $17: 1$ & 95 & n. d. \\
10 & $\begin{array}{l}\text { Cat-4 } \\
(1 \%)\end{array}$ & 1,5 & Full & $17: 1$ & 96 & n. d. \\
$11^{\mathrm{g}}$ & $\begin{array}{l}\text { Cat-4 } \\
(1 \%)\end{array}$ & 1,5 & Full & $>20: 1$ & 98 & n. d. \\
\hline a) 1a $(0.05$ mmol) \\
\hline
\end{tabular}

in $1 \mathrm{~mL}$ of toluene at $\mathrm{rt}$. b) Determined by ${ }^{1} \mathrm{H} \mathrm{NMR}$. ${ }^{\text {c) }}$ Determined by HPLC using chiral stationary phase. d) Opposite enantiomer was obtained. e) $\mathrm{CH}_{2} \mathrm{Cl}_{2}$ was used as solvent. f) $\mathrm{Et}_{2} \mathrm{O}$ was used as solvent. ${ }^{\text {g) }}$ The reaction was performed at $0{ }^{\circ} \mathrm{C}$. $\mathrm{Ar}=3,5-\left(\mathrm{CF}_{3}\right)_{2}-\mathrm{C}_{6} \mathrm{H}_{3}$.

As shown in Table 1, when $5 \mathrm{~mol} \%$ of quinine (Cat1) was used in toluene, full conversion was obtained within 2 hours, providing compound 3a in 5:1 diastereomeric ratio (d.r.) and poor enantiomeric excesses for both diastereoisomers (entry 1). Quinidine (Cat-2) afforded 3a with better d.r. (6:1), and enantiomeric excesses $(66 \%$ ee for the major diastereoisomer, entry 2). Cupreine derivative Cat-3, could catalyse the reaction but product 3a was obtained with poor diastereo- and enantioselectivities (entry 3). Quinine derived thiourea Cat-4 and quinine derived squaramide Cat-5, exhibited excellent reactivity with high stereocontrol, giving full conversion to product 3a with excellent d.r. ( $>20: 1)$ and high enantiomeric excess ( $96 \%$ ee with Cat-4 and 95\% ee with Cat-5, entries 4 and 5 respectively). With commercially available Takemoto's catalyst (Cat-6) a decreased in the diastereoselectivity was observed (4:1 d. r.; entry 6). Different solvents were tested with Cat4, achieving lower selectivities (entries 7 and 8). A reduction in the catalyst loading was then investigated (entries 9 and 10), observing similar enantioselectivities but slightly lower diasteroisomeric ratios. Finally, by using $1 \mathrm{~mol} \%$ of Cat-4 in toluene at $0{ }^{\circ} \mathrm{C}$ (entry 11), product 3a was gained with excellent stereoselectivity ( $>20: 1 \mathrm{dr}$ and $98 \%$ ee).

Having established the optimal reaction conditions (entry 11, Table 1) that are similar to the reported in the work of Wennemers for the addition of monothiomalonate to isatin-ketimines, ${ }^{8 \mathrm{c}}$ the scope of the reaction was evaluated (Scheme 1). First, $N$ substitution of oxindole nitrogen was investigated (Scheme 1, 3a-3f). Groups such as benzyl, methyl, allyl, methoxymethyl or phenyl were well tolerated, and the corresponding products were obtained with high diastereo- and excellent enantioselectivities. However, when the nitrogen was protected with an ethoxycarbonyl group, the corresponding product $\mathbf{3 f}$ was obtained with lower diastereo- and enantioselectivity. Meanwhile when a tosyl protecting group was used, very poor reactivity and diastereoselectivity was observed and the products were obtained as a nearly racemic mixtures. Next, the effect of substitution in the benzene ring of the $N$ benzyl protected isatin ketimines was studied (3g-3I). Different electron-donating ( $\mathrm{Me}$ or $\mathrm{MeO}$ ) or electronwithdrawing $\left(\mathrm{Cl}\right.$ or $\left.\mathrm{NO}_{2}\right)$, were tolerated at the 5 position of the isatin-derived ketimine, affording the corresponding products with good yields and high stereocontrol. Moreover, ketimines with substituents at 6 or 7 positions reacted smoothly, providing the tertiary amines 3 with good results. Next, the substrate scope with respect to 4-substituted pyrazolones (ethyl or benzyl) was evaluated (3m-3o) obtaining good values of diastereo- and enantioselectivity, although a decrease in the reactivity was observed. When 4methyl-2,5-diphenyl-pyrazolone was used as a nucleophile, poor d.r. and ee values were observed (3p) with Cat-4, although the diastereoselectivity could be increased with quinine derived squaramide (Cat-5). Finally, the reaction with 2,4,5-trimethylpyrazolone, gave compound $\mathbf{3 q}$ with a good d.r. and moderate enantioselectivity. Nevertheless, when Cat$\mathbf{5}$ was used, the product $\mathbf{3 q}$ was afforded with better d.r. (8:1) and excellent enantioselectivity (99\% ee). 


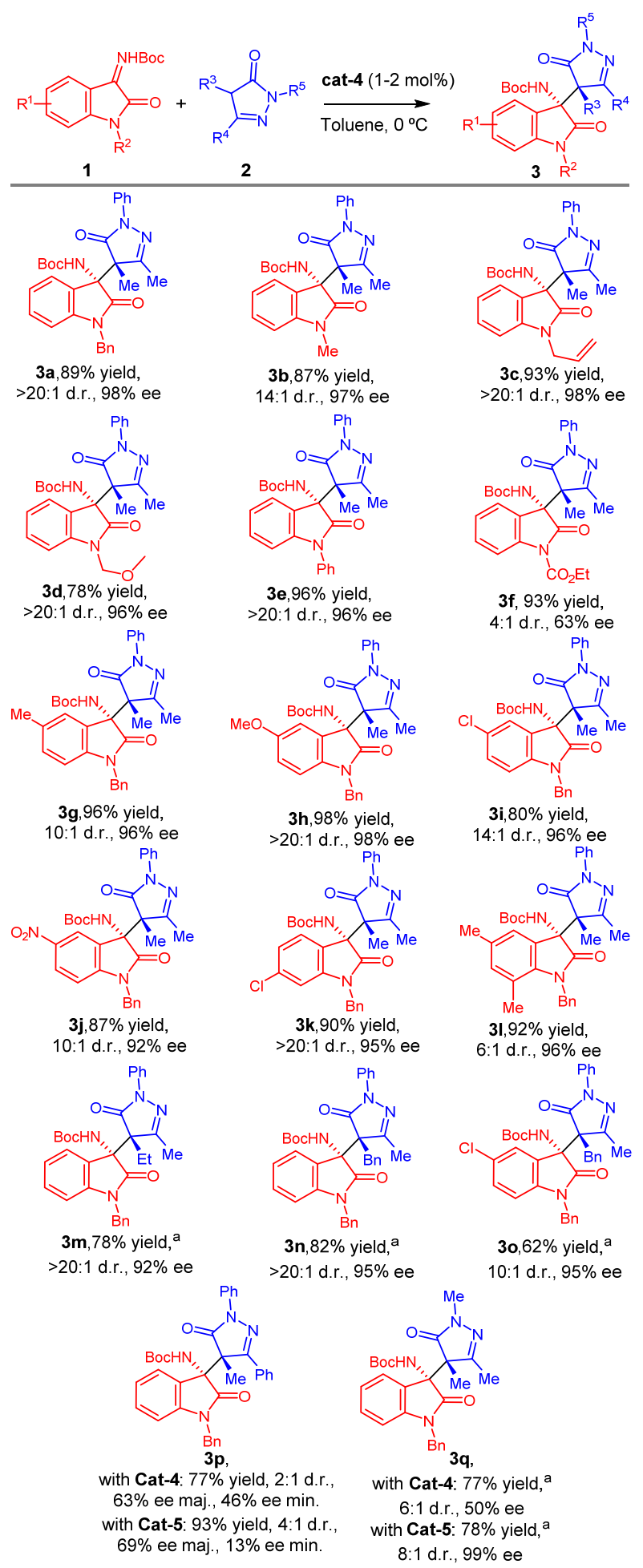

Scheme 1. Scope of the addition of pyrazolones to isatin derived $N$-Boc ketimines: $1(0.05 \mathrm{mmol}), 2(0.051 \mathrm{mmol})$ and Cat-4 $(1 \mathrm{~mol} \%)$ in $1 \mathrm{~mL}$ of toluene at $0{ }^{\circ} \mathrm{C}$. Isolated yields after column chromatography. Diastereoselectivities were determined by ${ }^{1} \mathrm{H}$ NMR of the crude reaction mixture. Enantioselectivities of the major diastereoisomer were determined by HPLC using chiral stationary phase. ${ }^{\text {a) }} 2$ mol $\%$ of catalyst was used.

The absolute configuration of the two stereogenic centers in compound $\mathbf{3 i}$ was determined to be (3R, 4 'S) on the basis of X-ray crystallographic analysis (Figure
2 ); the configuration of the rest of the products 3 was assigned on the assumption of a uniform mechanistic pathway. ${ }^{[18]}$

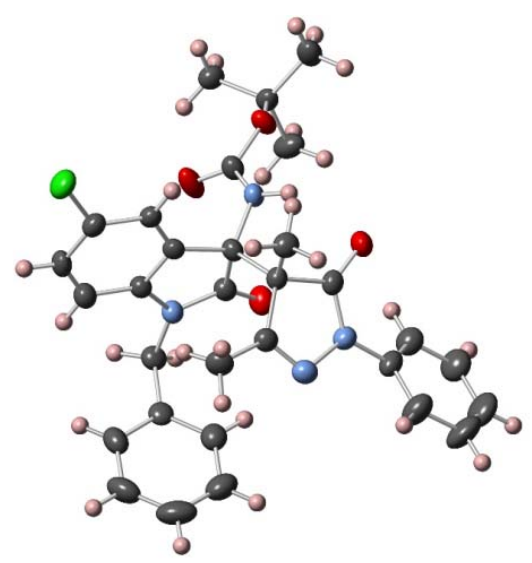

Figure 2. X-ray crystal structure of $\mathbf{3 i}$.

A plausible transition-state model is depicted in Scheme 2. The thiourea acts as bifunctional organocatalyst responsible for the preorientation and the activation of the substrates. While the isatin derived $N$-Boc ketimine moiety is activated upon formation of hydrogen bonds between the $N$-Boc group and the thiourea, the pyrazolone undergoes nucleophilic activation by hydrogen bonding with the quinuclidine moiety of the catalyst. ${ }^{[19]}$ The 4substituted pyrazolone will be directed to the Re-face of the ketimine, thus accounting for the observed enantioselectivity.

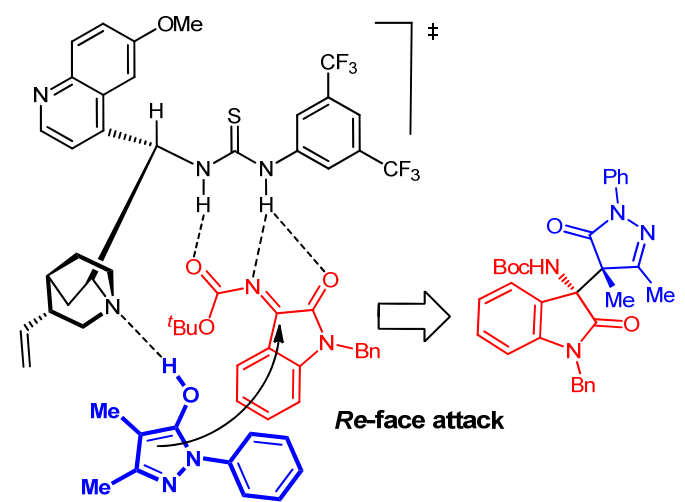

Scheme 2. Plausible transition-state model.

In summary, we have described the enantioselective amino alkylation of 4-substituted pyrazolones with isatin-derived $\mathrm{N}$-Boc ketimines catalysed by quinine derived thiourea organocatalysts. This approach provides a new methodology to synthesize optically active compounds containing vicinal tetrasubstituted stereocenters. The reaction shows a wide substrate scope for different $\mathrm{N}$-Boc imines and 4-substituted pyrazolones. The present study extends the scope of the catalytic asymmetric amino alkylation with isatin 
derived ketimines, providing a new class of amino oxindole derivatives. ${ }^{[3]}$ Studies to further extend the scope of this reaction and evaluation of the biological activities of compounds $\mathbf{3}$ are currently underway in our laboratory.

\section{Experimental Section}

\section{General Procedure}

A test tube containing ketimine $\mathbf{1}(0.1 \mathrm{mmol})$, pyrazolone 2 $(0.1 \mathrm{mmol})$ and thiourea Cat-4 $(0.6 \mathrm{mg}, 0.001 \mathrm{mmol})$ was purged with $\mathrm{N}_{2}$. Then, $1.0 \mathrm{~mL}$ of toluene was added and the mixture stirred at $0{ }^{\circ} \mathrm{C}$ until the reaction was complete (TLC). Finally, the reaction mixture was directly poured to the column chromatograpy, using hexane:EtOAc (95:5) as eluent to afford product 3 .

\section{Acknowledgements}

Financial support from the MINECO (Gobierno de España and FEDER (EU)) (CTQ2013-47949-P) and from Generalitat Valenciana (ISIC2012/001) is gratefully acknowledged. C. V. thanks MINECO for JdC contract. Access to NMR, MS and X-ray facilities from the Servei central de support a la investigació experimental (SCSIE)-UV is also acknowledged.

\section{References}

[1] a) C. Du, L. Li, Y. Li, Z. X. Xie, Angew. Chem. 2009, 121, 7993; Angew. Chem. Int. Ed. 2009, 48, 7853; b) B. M. Trost, M. Osipov, Angew. Chem. 2013, 125, 9346; Angew. Chem. Int. Ed. 2013, 52, 9176; c) H. L. Zhang, L. Hong, H. Kang, R. Wang, J. Am. Chem. Soc. 2013, 135, 14098; d) Z.-Y. Cao, X.-M. Wang, C. Tan, X.L. Zhao, J. Zhou, K.-L. Ding, J. Am. Chem. Soc. 2013, 135, 8197; e) K. Ohmatsu, N. Imagawa, T. Ooi, Nat. Chem. 2014, 6, 47; f) R. M. Lemieux, A. I. Meyers, J. Am. Chem. Soc. 1998, 120, 5453; g) C. Du, L. Li, Y. Li, Z. Xie, Angew. Chem., 2009, 121, 7993; Angew. Chem., Int. Ed. 2009, 48, 7853; h) K. Ohmatsu, Y. Ando, T. Ooi, J. Am. Chem. Soc. 2013, 135, 18706; i) R. Alam, T. Vollgraff, L. Eriksson, K. J. Szabo, J. Am. Chem. Soc. 2015, 137, 11262; j) L. Gao, G.-S. Hwang, D. H. Ryu, J. Am. Chem. Soc. 2011, 133, 20708; k) A. Jolit, P.M. Walleser, G. P. A. Yap, M. A. Tius, Angew. Chem., 2014, 126, 6294; Angew. Chem., Int. Ed. 2014, 53, 6180.

[2] a) J. Christhofers, A. Baro in Quaternary Stereocenters: Challenges and Solutions for Organic Synthesis, WileyVCH, Weinheim, 2005; b) E. A. Peterson, L. A. Overman, Proc. Natl. Acad. Sci. USA 2004, 101, 11943 ; c) B. M. Trost, C. Jiang, Synthesis 2006, 369; d) J. P. Das, I. Marek, Chem. Commun. 2011, 47, 4593; e) I. Marek, Y. Minko, M. Pasco, T. Mejuch, N. Gilboa, H. Chechick, J. P. Das, J. Am. Chem. Soc. 2014, 136, 2682; f) M. Büschleb, S. Dorich, S. Hanessian, D. Tao, K. B. Schenthal, L. E. Overman, Angew. Chem. 2016, 128, DOI: 10.1002/ange.201507549; Angew. Chem., Int. Ed. 2016, 54, DOI: $10.1002 /$ anie. 201507549

[3] a) P. Chauhan, S. S. Chimni, Tetrahedron: Asymmetry, 2013, 24, 343; (b) J. Kaur, S. S. Chimni, S. Mahajan, A.
Kumar, RSC Adv. 2015, 5, 52481; c) J.-S. Yu, F. Zhou, Y.-L. Liu, J. Zhou, Synlett, 2015, 26, 2491.

[4] a) K. Bernard, S. Bogliolo, J. B. Ehrenfeld, Br. J. Pharmacol., 2005, 144, 1037; b) T. Oost, G. Backfisch, S. Bhowmik, M. M. van Gaalen, H. Geneste, W. Hornberger, W. Lubisch, A. Netz, L. Unger, W. Wernet, Bioorg. Med. Chem. Lett., 2011, 21, 3828; c) T. Shimazaki, M. Iijima, S. Chaki, Eur. J. Pharmacol. 2006, 543, 63; d) G. Decaux, A. Soupart, G. Vassart, Lancet 2008, 371, 1624.

[5] M. Ochi, K. Kawasaki, H. Kataoka, Y. Uchio, H. Nishi, Biochem. Biophys. Res. Commun., 2001, 283, 1118.

[6] a) M. Rottmann, C. McNamara, B. S. K. Yeung, M. C. S. Lee, B. Zou, B. Russell, P. Seitz, D. M. Plouffe, N. V. Dharia, J. Tan, S. B. Cohen, K. R. Spencer, G. GonzalezPaez, L. Lakshiminarayana, A. Goh, R. Suwanarusk, T. Jegla, E. K. Schmitt, H.-P. Beck, R. Brun, F. Nosten, L. Renia, V. Dartois, T. H. Keller, D. A. Fidock, E. A. Winzeler, T. T. Diagana, Science, 2010, 329, 1175; b) B. K. S. Yeung, B. Zou, M. Rottmann, S. B. Lakshminarayana, S. H. Ang, S. Y. Leong, J. Tan, J. Wong, S. Keller-Maerki, C. Fischli, A. Goh, E. K. Schmitt, P. Krastel, E. Francotte, K. Kuhen, D. Plouffe, K. Henson, T. Wagner, E. A. Winzeler, F. Petersen, R. Brun, V. Dartois, T. T. Diagana, T. H. Keller, J. Med. Chem., 2010, 53, 5155.

[7] Selected examples: a) N. Hara, S. Nakamura, M. Sano, R. Tamura, Y. Funahashi, N. Shibata, Chem. Eur. J. 2012, 18, 9276; b) W. Yan, D. Wang, J. Feng, P. Li, D. Zhao, R. Wang, Org. Lett. 2012, 14, 2512; c) D. Wang, J. Liang, J. Feng, K. Wang, Q. Sun, L. Zhao, D. Li, W. Yan, R. Wang, Adv. Synth. Cat. 2013, 355, 548; d) Y.-L. Liu, J. Zhou, Chem. Commun. 2013, 49, 4421; e) T. Arai, E. Matsumura, H. Masu, Org. Lett. 2014, 16, 2768; f) M. Holmquist, G. Blay, J. R. Pedro, Chem. Commun. 2014, 50, 9309; g) S. Nakamura, K. Hyodo, M. Nakamura, D. Nakane, H. Masuda, Chem. Eur. J. 2013, 19, 7304; h) J. $\mathrm{Xu}, \mathrm{C} . \mathrm{Mou}, \mathrm{T}$. Zhu, B.-A. Song, Y. R. Chi, Org. Lett. 2014, 16, 3272; i) J. Feng, W. Yan, D. Wang, P. Li, Q. Sun, R. Wang, Chem. Commun. 2012, 48, 8003; j) M. Montesinos-Magraner, C. Vila, R. Cantón, G. Blay, I. Fernández, M. C. Muñoz, J. R. Pedro, Angew. Chem. 2015, 127, 6418; Angew. Chem. Int. Ed. 2015, 54, 6320; k) S. Nakamura, S. Takahashi, D. Nekane, H. Matsuda, Org. Lett. 2015, 17, 2416; 1) M. Holmquist, G. Blay, M. C. Muñoz, J. R. Pedro, Adv. Synth. Catal. 2015, 357, 3857; m) Y.-L. Lin, F. Zhou, J.-J. Cao, C.-B. Ji, M. Ding, J. Zhou, Org. Biomol. Chem. 2010, 8, 3847; n) A. Kumar, J. Kaur, S. S. Chimni, A. K. Jassal, RSC Adv. 2014, 4, 24816; o) H. Lv, B. Tiwari, J. Mo, C. Xing, Y. R. Chi, Org. Lett, 2012, 14, 5412; p) F.-L. Hu, Y. Wei, M. Shi, S. Pindi, G. Li, Org. Biomol. Chem. 2013, 11, 1921; q) J. George, B. Sridhar, V. S. Reddy, Org. Biomol. Chem. 2014, 12, 1595; r) T. Arai, K. Tsuchiya, E. Matsumura, Org. Lett. 2015, 17, 2416; s) K. Zhao, T. Shu, J. Jia, G. Raabe, D. Enders, Chem. Eur. J. 2015, 21, 3933; t) S. Nakamura, S. Takahashi, D. Nakane, H. Masuda, Org. Lett. 2015, 17, 106.

[8] a) J. Zhao, B. Fang, W. Luo, X. Hao, X. Liu, L. Lin, X. Feng, Angew. Chem., 2015, 127, 243; Angew. Chem., Int. 
Ed. 2015, 54, 241; b) T. Liu, W. Liu, X. Li, F. Peng, Z. Shao, J. Org. Chem. 2015, 80, 4950; c) O. D. Engl, S. P. Fritz, H. Wennemers, Angew. Chem., 2015, 127, 8311; Angew. Chem., Int. Ed. 2015, 54, 8193; d) H. M. Zhang, Z. H. Gao, S. Ye, Org. Lett. 2014, 16, 3079; f) Z. Tang, Y. Shi, H. Mao, X. Zhu, W. Li, Y. Cheng, W.-H. Zheng, C. Zhu, Org. Biomol. Chem. 2014, 12, 6085; g) Y. Zhu, E. Zhang, C. Luo, X. Li, J.-P. Cheng, Tetrahedron 2015, 71, 4090; h) X. Liu, J. Zhang, L. Zhao, S. Ma, D. Yang, W. Yan, R. Wang, J. Org. Chem. 2015, 80, 12651; i) K. Zhao, Y. Zhi, X. Li, R. Puttreddy, K. Rissasen, D. Enders, Chem. Commun., 2016, 52, 2249.

[9] G. Varvounis, in Pyrazol-3-ones. Part IV: Synthesis and Applications, ed. A. R. Katritzky, Advances in Heterocyclic Chemistry, Academic Press, New York, 2009, vol. 98, p. 143

[10] a) N. Yokoyama, B. Ritter, A. D. Neubert, J. Med. Chem. 1982, 25, 337; b) R. I. Fryer, P. Zhang, R. Rios, Z.-Q. Gu, A. S. Basile, P. Skolnick, J. Med. Chem. 1993, 36, 1669; c) L. Savini, P. Massarelli, C. Nencini, C. Pellerano, G. Biggio, A. Maciocco, G. Tuligi, A. Carrieri, N. Cinone, A. Carotti, Bioorg. Med. Chem. 1998, 6, 389; d) M. G. Ferlin, G. Chiarelotto, S. D. Acqua, E. Maciocco, M. P. Mascia, M. G. Pisu, G. Biggio, Bioorg. Med. Chem. 2005, 13, 3531; e) A. Kimata, H. Nakagawa, R. Ohyama, T. Fukuuchi, S. Ohta, T. Suzuki, N. Miyata, J. Med. Chem. 2007, 50, 5053; f) O. A. Attanasi, P. Filippone, B. Guidi, T. Hippe, F. Mantellini, L. F. Tietze, Tetrahedron Lett. 1999, 40, 9277; g) F. Lehmann, M. Holm, S. Laufer, J. Comb. Chem. 2008, 10, 364; h) F. Caruso, M. Rossi, J. Tanski, R. Sartori, R. Sariego, S. Moya, S. Diez, E. Navarrete, A. Cingolani, F. Marchetti, C. Pettinari, J. Med. Chem. 2000, 43, 3665.

[11] a) H. Yoshida, H. Yanai, Y. Namiki, K. Fukatsu-Sasaki, N. Furutani, N. Tada, CNS Drug Rev., 2006, 12, 9; b) W. Ji Yuan, T. Yasuhara, T. Shingo, K. Muraoka, T. Agari, M. Kameda, T. Uozumi, N. Tajiri, T. Morimoto, M. Jing, T. Baba, F. Wang, H. Leung, T. Matsui, Y. Miyoshi, I. Date, BMC Neurosci., 2008, 9, 75.

[12] 'Dipyrone', Martindale: The Complete Drug Reference, ed. A. Brayfield, Pharmaceutical Press, 2014.

[13] a) Y. Fujimori, K. Katsuno, I. Nakashima, Y. IshikawaTakemura, H. Fujikura, M Isaji, J. Pharmacol. Exp. Ther. 2008, 327, 268; b) S. Mudaliar, D. A. Armstrong, BA, A. A. Mavian, R. O'Connor-Semmes,P- K. Mydlow, J.
Ye, E. K. Hussey, D. J. Nunez, R. R. Henry, R. L. Dobbins, Diabetes Care 2012, 35, 2198.

[14] P. Chauhan, S. Mahajan and D. Enders, Chem. Commun., 2015, 51, 12890

[15] a) Y.-H. Liao, W.-B. Chen, Z.-J. Wu, X.-L. Du, L.-F. Cun, X.-M. Zhang, W.-C. Yuan, Adv. Synth. Catal. 2010, 352, 827; b) Z. Wang, Z. Yang, D. Chen, X. Liu, L. Lin, X. Feng, Angew. Chem. Int. Ed. 2011, 50, 4928; c) Z. Yang, Z. Wang, S. Bai, X. Liu, L. Lin, X. Feng, Org. Lett. 2011, 13, 596; d) Z. Wang, Z. Chen, S. Bai, W. Lei, X. Liu, L. Lin, X. Feng, Angew. Chem., 2012, 124, 2830; Angew. Chem. Int. Ed. 2012, 51, 2776; (e) A. Mazzanti, T. Calbet, M. Font-Bardia, A. Moyano, R. Rios, Org. Biomol. Chem. 2012, 10, 1645; f) M. Šimek, M. Remeš, J. Veselý, R. Rios, Asian, J. Org. Chem. 2013, 2, 64; g) Z.-L. Tao, W.-Q. Zhang, D.-F. Chen, A. Adele, L.-Z. Gong, J. Am. Chem. Soc. 2013, 135, 9255.

[16]During the preparation of this manuscript an elegant organocatalytic addition of 4-nonsubstituted pyrazolones to isatin derived ketimines have been described: X. Bao, B. Wang, L. Cui, G. Zhu, Y. He, J. Qu, Y. Song, Org. Lett. 2015, 17, 5168.

[17] a) S.-K. Tian, Y.-G. Chen, J. F. Hang, L. Tang, P. McDaid, L. Deng, Acc. Chem. Res. 2004, 37, 621; b) T. Marcelli, H. Hiemstra, Synthesis 2010, 1229; c) S. Connon, Chem. Eur. J. 2006, 12, 5418; d) A. G. Doyle, E. N. Jacobsen, Chem. Rev. 2007, 107, 5713; e) S. J. Connon, Chem. Commun. 2008, 2499; f) Y. Takemoto, Chem. Pharm. Bull. 2010, 58, 593; g) T. J. Auvil, A. G. Schafer, A. E. Mattson, Eur. J. Org. Chem. 2014, 2633. For seminal works using Cat-4 for the addition to imines: h) J. Song, Y. Wang, L. Deng, J. Am. Chem. Soc. 2006, 128, 6048; e) L. Bernardi, F. Fini, R. P. Herrera, A. Ricci, V. Sgarzani, Tetrahedron 2006, 62, 375.

[18] CCDC-1444032 (3i) contains the supplementary crystallographic data for this paper. These data can be obtained free of charge from The Cambridge Crystallographic Data Centre via www.ccdc.cam.ac.uk/data_request/cif.

[19] a) P. Kumari, S. Barik, N. H. Khan, B. Ganguly, R. I. Kureshy, S. H. R. Abdiab, H. C. Bajaj, RSC Adv., 2015, 5, 69493; b) D. Hack, P. Chauhan, K. Deckers, Y. Mizutani, G. Raabe, D. Enders, Chem. Commun., 2015, $51,2266$. 


\section{COMMUNICATION}

Organocatalytic Enantioselective Alkylation of Pyrazol-3-ones with Isatin-Derived Ketimines: Stereocontrolled Construction of Vicinal

Tetrasubstituted Stereocenters

Adv. Synth. Catal. Year, Volume, Page - Page

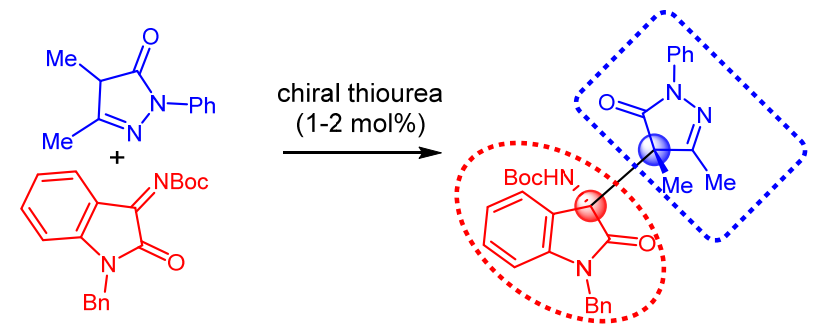

Fares Ibrahim Amr, ${ }^{a}$ Carlos Vila, ${ }^{\text {a* }}$ Gonzalo Blay, ${ }^{\mathrm{a}}$ M. Carmen Muñoz and José R. Pedro ${ }^{\mathrm{a}, *}$

Vicinal chiral tetrasubstituted stereocenters

- Bioactive oxindole skeleton

- Bioactive pyrazolone skeleton

- High dr and ee values 